\title{
KREATIVITAS DAN INOVASI USAHA MELENIAL DUKUNG PEREKONOMIAN NEGARA DITENGAH PANDEMI COVID -19
}

\author{
Oleh : Sudiyarti
}

Dosen Fakultas Ilmu Sosial dan Ilmu Politik Universitas 17 Agustus 1945 Samarinda, Indonesia

\begin{abstract}
The theme of melenial business management has a definition that is: managing or regulating human needs individually in particular and for society in general. Efforts to be inspired from contact, through the world of digital business and the Internet, in the midst of the covid-19 pandemic outbreak, with efforts and innovations and technological developments so that it will greatly support the country's economy. In the business world, the melenial generation is believed to bring change and become an economic power in particular in Indonesia and in developing countries in general. In addition to being active as Internet users, the current generation can also strengthen opportunities in times of crisis gelobal such as at this time, to earn income during the Covid-19 Pandemic as it is today.
\end{abstract}

Key word: entrepreneurship in the middle of a pandemic.

\begin{abstract}
ABSTRAK
Tema manajemen usaha melenial memiliki definisi yaitu : mengelola atau mengatur kebutuhan manusia secara individu pada khususnya dan untuk masyarakat pada umumnya. Usaha melenial terisnpirasi dari kontak, melalui dunia usaha digital dan Internet, ditengah wabah pandemi covid - 19, dengan usaha dan Inovasi dan perkembangan teknologi sehingga akan sangat mendukung perekonomian Negara. Dalam dunia usaha, generasi melenial dipercaya membawa perubahan dan menjadi kekuatan ekonomi pada khususnya di Indonesia dan dinegara negara berkembang pada umumnya.Selain aktif menjadi pengguna Internet, generasi melenial saat ini juga bisa memperkuat peluang disaat krisis gelobal seperti pada saat ini, untuk mendapatkan penghasilan di masa Pandemi Covid - 19 seperti saat ini.
\end{abstract}

Keyword : kewirausahaan di tengah pandemi. 


\section{PENDAhuluan}

\section{A. Latar Belakang}

Kemudahan informasi yang ada saat ini menjadi kesempatan emas bagi milenial untuk mulai mencari ide-ide menarik. Ide-ide tersebut direalisasikan dengan produk yang mampu menyelesaikan persoalan sosial di tengah pandemi. Buktinya, kini banyak milenial yang bisa memanfaatkan pandemi menjadi peluang bisnis yang unik dan menarik, seperti bisnis masker, bisnis kuliner rumahan, dan sederet bisnis yang ternyata menarik banyak orang. Tentunya, kondisi ini bisa menjadi bukti bahwa milenial punya peran dalam membantu sektor perekonomian Indonesia lewat Usaha Mikro, Kecil, dan Menengah (UMKM) yang mereka lakukan. Apalagi UMKM sangat berpengaruh terhadap pertumbuhan ekonomi di Indonesia. Ditambah dengan kemajuan teknologi, UMKM di Indonesia terus melakukan diversifikasi produk untuk memenuhi berbagai kebutuhan masyarakat di berbagai daerah. Menurut Badan Pusat Statistik (BPS) jumlah Usaha Mikro Kecil dan Menengah (UMKM) mencapai 64 juta. Angka tersebut mencapai 99,9 persen dari keseluruhan usaha yang beroperasi di Indonesia.dalam melakukan diverifikasi produk untuk memenuhi berbagai kebutuhan masyarakat di berbagai daerah. Menurut badan pusat statistik (BPS ) Jumlah Usaha mikro kecil dan menengah (UMKM) mencapai 64 juta, angka tersebut mencapai 9,99 persen dari keseluruhan usaha yang berpotensi di Indonesia.

Model usaha dan perdagangan dalam era digital sekarang ini sudah tidak bias lagi dibendung dengan kegiatan serupa yang masih manual. Masyarakat pada umumnya sudah "melek"aplikasi, dimana denganaplikasi tersebut yang menjadi jembatan bagi "awam" dalam menggunakan teknologi informasi, pada khususnya yang berbasis perdagangan commerce.

Kemajuan teknologi selalu memiliki dua mata pisau, dimana satu sisinya meningkatkan keuntungan sementara sisilainnya memakan korban kerugian bahkan sampaimengalami kebangkrutan. Sudah sering kali kita dengar sekarang ini banyak gerai toko on line yang terpaksa harus menutup gerainya karena pengunjung yang kian sepi, akan tetapi menurut Bank Indonesia peredaran uang bahkan bisa menunjukkan peningkatan. Kemana larinya Transaksi, tentunya yang kian meningkat terjadi pada toko-toko one line sekali gus juga adanya usaha usaha distribusi barang- barang dengan layanan one line.

Kewirausaha one line sekarang tidak dituntut untuk bisa membuat aplikasi sendiri, dengan menumpang aplikasi yang sudah ada, kita sudah bisa berusaha (menjadi wirausahawan) one line sangatlah mudah dan cepat.

Kewirausahaan dan inovasi adalah munculnya disiplin untuk merespon secara aktif perubahan dalam dunia E- Commerce. 
Pandemi Covid-19 yang berlangsung sejak awal 2020 cukup memberikan dampak yang sangat signifikan pada perekonomian di Indonesia termasuk Kalimantan.. Tidak hanya dialami oleh pelaku usaha skala besar. Hal serupa juga ikut dialami para pelaku Usaha Mikro, Kecil dan Menengah (UMKM).

\section{B. Rumusan Masalah}

1. Bagaimanakah manajemen dan kreativitas pelaku usaha pada pemilihan jenis menu, pemilihan nama untuk usaha pemilihan lokasi, penciptaan citarasa untuk setiap menu,penciptaan ide, dalam diversifikasi produk usaha kuliner?

2. Bagaimanakah inovasi pelaku usaha melineal dan digital dalamproduk yang ditawarkan, termasuk fasilitas usaha, promosi produk dan produk yang tidak di sukai atau kurang di minati konsumen dalam diversifikasi produk kuliner dan produk lain?

3. Bagaimanakah peran kreaktivitas dan inovasi dalam diversifikasi produk kuliner yang dilakukan pelaku berwirausaha?

Kendati demikian, pelaku UMKM milenialperlu diberi support dan bantuan dari banyak pihak agar Pemulihan Ekonomi Nasional (PEN) dapat tercapai. Sebab bagaimanapun, selama pandemi COVID-19 ini, sektor UMKM jadi salah satu sektor paling terdampak. Banyak dari pelaku UMKM yang harus gulung tikar karena kurva permintaannya merosot.

Melihat kondisi tersebut, sebagai e-commerce terdepan, Blibli memberikan ruang bagi UMKM untuk mengembangkan usahanya. Sampai saat ini, Blibli memiliki lebih dari 65 ribu UMKM dan lebih dari 50 persen pelaku usaha berasal dari generasi milenial. Mereka menghadirkan beragam produk di Blibli, mulai dari kuliner, kriya, fesyen hingga pernak-pernik.

Bagi Blibli, UMKM memiliki peranan penting dalam pemulihan ekonomi ini. UMKM telah menjadi penyelamat ekonomi dalam negeri saat krisis 1998 dan 2008. UMKM juga memiliki posisi strategis yang mampu menyerap hampir 97 persen tenaga kerja Indonesia dan menyumbang 61.1 persen PDB.

\section{Tujuan Penelitian}

1. Untuk mengetahui prilaku dan kreativitas berwirausaha pada pemilihan jenis menu kuliner atau jenis barang yang ditawarkan, pemilihan nama bidang usaha, pemilihanlokasi, berwirausaha, penciptaan cita rasa untuk tiap menu yang di tawarkan dalam diversifikasi produkkuliner one line.

2. Untuk mengetahui inovasi pelaku usaha pada produk yang di tawarkan, fasilitas usaha, promosi produk, produk yang tidak di sukai atau yang 
kurang di minati oleh konsumen, yang dilakukan oleh pelaku usaha one line.

3. Untuk mengetahui peran kreativitas dan inovasi dalam diversifikasi produkkuliner dan barang yang ditawarkan dan dilakukan oleh pelaku usaha kuliner on line.

\section{A. Kreativitas}

\section{KERANGKA DASAR TEORI}

Devinisi kreativitas dalam dimensi proses, merupakan upaya dalam mendevinisikan kreativitas yang berfokus pada proses berfikir sehingga memunculkan ide-ide unik dari kreatif

Devinisi kreativitas dalam dimensi produk, merupakan upaya dalam mendevinisikan kreativitas yang berfokum dakam produk individu atau person yang di fokuskan pasa proses produksi, atau apa yang di hasilkan dalam kreativitas dengan pendekatan yang menekankan faktor proses atau dorongan baikdorongan internal atau individu, berupa hasrat atau keinginan untuk menciptakan secara kreatif atau dorongan sosial eksternal, dan dari lingkungan sosial lain yang kreativitas.

Devinisi Phodes (Munandar 2012) mengatakan kreativitas dapat di devinisikan dalam empat demensi sebagai Four P.s Creativity yaitu : demensi Prson, Proses, Press dan Product.

\section{B. Inovasi}

Inovasi adalah kreativitas yang di terjemahkan menjadi sesuatu yang dapat di implementasikan dan memberikan nilai tambah atas sumber daya yang kita miliki. Jadi untuk senaantiasa dapat berinovasi dan memerlukan kecerdasan berkreatif (creative intelligence)

Pada prinsipnya manusia memiliki kapasitas tertentu untuk mengingat berbagai pengetahuan dan pengalaman.

Semakin luas wawasan seseorang, cenderung semakin tinggi kreativitasnya

Untukmeningkatkan daya kreativitasnya, dapat dilakukan dengan memperbanyak akumulasi pengetahuan yang produktif.

Selanjutnya pikiran sadar dan pikiran di bawah sadar, manusia akan melakukan proses inkubasi. Pada tahap ke tiga yaitu pengalaman ide. Ide akan mencuat walaupunide ituseringmuncul justru pada saat tidak sedang melakukan pekerjaan yang relevan.

Pada tahapke empat dilakukan evaluasi dan implementasi ide. Tahapan ini adalah yang paling berat karena di butuhkan komitmen dan dedikasi untuk merealisasikan ide menjadi sesuatu yang kongkrit, hasil dari tahapan ini adalah inovasi ( Wijayanto; 2012). 


\section{Pelaku Usaha}

Menurut kamus besar bahasa Indonesia pengertian pelaku adalah orang yang melakukan sesuatu perbuatan atau merupakan pelaku utama dalam perubahan situasi tertentu, sedangkan pengertian usaha adalah kegiatan dengan menggerakkan tenaga, pikiran atau badan untuk mencapai suatu maksud, pekerjaan atau perbuatan, prakarsa dan ikhtias, daya upaya, menurut pasal 1 (ayat 3) nomor 8 tahun 1999, tentang perlindungan konsumen, menyatakan bahwa devinisi prilaku usaha adalah pelaku usaha setiap orang.

Karenanya, e-commerce membuka peluang bagi UMKM dalam hal mengakselerasi transformasi digital mereka. Kementerian Koperasi dan UKM mencatat. setidaknya sejak pandemi terjadi, penjualan di e-commerce naik hingga 26 persen atau mencapai 3,1 juta transaksi per hari. Dengan mengadopsi platform teknologi, termasuk e-commerce, UMKM dapat menjangkau konsumen dengan lebih mudah dan lebih luas, sehingga bisnisnya pun bisa berkembang walau di tengah pandemi.

Selama pandemi, berbagai inisiatif Blibli berhasil menarik semakin banyak UMKM untuk go digital. Dari awal pertama kali kategori khusus UMKM di Blibliyaitu Galeri Indonesia berdiri dan hingga akhir September tahun ini sudah terdapat lebih dari 65 ribu seller UMKM yang bergabung di Blibli.

Untuk menguatkan dukungan Blibli terhadap UMKM, Blibli berkolaborasi dengan berbagai stakeholder, khususnya bersama pemerintah, dengan mendukung program Bangga Buatan Indonesia (BBI) yang dikolaborasikan dengan kampanye \#KarenaLokalNo1 dan gerakan \#PejuangLokal untuk menghadirkan deretan produk UMKM terbaik di Blibli. Rangkaian kegiatan ini bertujuan mendorong pelanggan untuk bangga membeli produk lokal. Tak hanya itu, Blibli juga akan memperkenalkan produk UMKM yang sebagian besar dikelola anak muda di program Ideafest 2020 pada November 2020.

Selain itu, Blibli juga melanjutkan kerjasama dengan pemerintah daerah, termasuk mendukung Pasar Kreatif Bandung 2020 bersama pemkot Bandung, dengan menghadirkan UMKM terbaik dari kota tersebut di platform Blibli. Blibli juga meluncurkan Galeri Mesin Lokal bersama Kementerian Perindustrian untuk memudahkan UMKM dalam membeli alat produksi dan memberdayakan UMKM kategori kuliner dengan mengadakan festival kuliner online di platform Blibli, antara lain Festival Nasi Online yang menyediakan ratusan menu dari 70 restoran lokal. Dengan begitu, UMKM semakin terbantukan dalam menjalankan usaha dan mengadopsi teknologi digital sebagai persiapan menghadapi Industry 4.0. 


\section{METODOLOGI PENELITIAN}

Bentuk penelitian ini menggunakan metode penelitian Diskriptif, dengan pendekatan analisis kkualitatif. Menurut Moleong (2013), penelitian kualitatif adalah penelitian yang bermaksud untuk memahami fenomena tentang apa yang dialami oleh subyek penelitian misalnya prilaku, persepsi,motifasi, tindakan dan lain - lain,secara holistik dan dengan cara diskripsi dalam bentuk kata- kata dan bahasa, pada suatu kontek khusus yang alamiah dan dengan memanfaatkan berbagai metode ilmiah.

Penelitian ini bertujuan untuk memberikan pemahaman yang lebih baik tentang sifat pelengkap kewirausahaan dan inovasi, melalui studi Emperis perusahaan melenial one lane untuk mendapatkan hasil yang layak.

Penulis telah memutuskan untuk menggunakan Tinjauan literatur terkini tentang inovasi kewirausahaan dengan analisis studi kasus dari berbagai sumber. Selain itu wawancara dan opservasi langsung dilakukan untuk menguji persepsi pengusaha E- bisnis one line dan e-commerce tentang kewirausahaan dan inovasi serta faktor- faktor yang mempengaruhi pengembangan dan integrasi kewirausahaan dan inovasi.

Tujuan utama dari tinjauan literatur adalah untuk menyusun teori dan pengetahuan dasar tentang kewirausahaan dan inovasi, mengeksplorasi hubungan konseptual di antara keduanya. Selain itu penelitian Web ini dilakukan untuk mendukung kajian literatur dari sumber yang di sediakan oleh penelitian serta memberikan gambaran pemahaman untuk mengekplorasi pengembangan nilai tambah hasil wieausaha dan inovasi ditengah krisis ekonomi global karena terjadinya

Sumber data yang digunakan dalam penelitian ini adalah : Data primer, yaitu data yang diperoleh langsung melalui wawancara kepada Pemilik badan usaha, dan para konsumen, maupun informasi yang berkaitan dengan prilaku pemilik wirausaha.

Teknik pengumpulan data, analisis data analisis data yang dipergunakan pola penelitian induktif, dengan mengikuti model Analisis Interaktif.

\section{PEMBAHASAN}

\section{A. Hadirkan Program dan Fitur untuk UMKM}

Blibli secara aktif turut mendorong digitalisasi UMKM serta melakukan pemberdayaan para mitra seller lainnya melalui semangat \#Ayo Bersama. Dengan semangat ini, Blibli menghadirkan berbagai macam program dan fitur yang menguntungkan seller (UMKM) untuk memperkenalkan produknya kepada masyarakat. Apa saja? 


\section{Blibli memberikan berbagai insentif agar UMKM ingin go online}

Pemberian Insentif termasuk meniadakan deposit dan komisi adalah langkah Blibli untuk mengurangi cost UMKM untuk go online. Selain itu, Blibli juga memberi dana untuk melakukan digital marketing untuk meningkatkan awareness terhadap brand dan produk UMKM tersebut.

\section{Fitur Blibli dongkrak penjualan produk UMKM}

Blibli menyediakan berbagai fitur untuk mempercepat proses jual beli, salah satunya Fulfillment by Blibli (FBB) untuk para seller yang menjual produk kebutuhan sehari-hari. Melalui FBB, para seller dapat memiliki fasilitas gratis titip barang di gudang, sehingga seluruh proses penjualan akan ditangani dengan baik oleh tim Blibli. FBB menggunakan jaringan 20 warehouse dan 32 hub yang tersebar di 15 kota besar.

\section{Mengadakan workshop dan training}

Sampai saat ini, Blibli tak henti-hentinya menggelar ntrepreneurship workshops and trainings yang digelar secara virtual, baik webinar dan IG Live. Blibli juga menyediakan e-newsletter untuk seller. E-newsletter tersebut berisi tips dan trik sukses berjualan di Blibli. Tercatat, Blibli sudah menggelar 470 pelatihan dalam 3 tahun terakhir.

\section{B. Hubungan konsepsional antara Kewirausahaan dan Inovasi}

Inovasi ekonomi khususnya telah menarik perhatian yang meningkat dalam beberapa tahun terakhir (18), (19), (20).Sudho (2) merangkum teori dasar ekonomi inovasi dan mengindentifikasi tiga paradigma yang bersaing,dalam diskusi teoritis inovasi saat ini :

$>$ Paradigma pengusaha

$>$ Paradigma teknologi - ekonomi

$>$ Paradigma strategis.

Paradigma pengusaha dapat dilacak pada tahun 1990an, ketika Schumpeter pertama mencoba menjalin antara usaha dan inovasi dalam teori, dan memandang pengusaha sebagai inovator, berkontribusi terhadap pertumbuhan ekonomi. Konsep wirausaha sebagai inovator mendasari paradigma pengusaha dimana peran pengusaha disorot dalam proses inovasi.

Kewirausahaan adalah tentang menciptakan sesuatuyang sebelumnya tidak ada, penciptaan menambah nilai bagi seseorang, individu dan masyarakan dan didasarkan pada persepsi dan kesempatan menangkap (5) Inovasi adalah alat kewirausahaan khusus dimana para pengusaha memanfaatkan perubahan sebagai peluang untuk kegiatan bisnis, atau layanan yang berbeda. Ada banyak tumpang tindih antara kewiraswastaan berprestasi dalam wawancara tersebut. 


\section{Isu dan Tantangan menghadapi Kewirausahaan dan Inovasi dalam E-commerce}

\section{Studi kasus}

Perusahaan yang dipilih untuk studi kasus mencakup berbagai sektor bisnis ( misalnya pengecer buku online perusahaan manufaktur, industri, Farmasi, kuliner dll ) yang beroperasi di berbagai negara dan budaya dan terlebih lagi memiliki sejarah yang berbeda. Dan berbeda pula lamanya beroperasi, hanya beberapa kasus yang di laporkan karena keterbatasan ruang.

\section{Studi kasus 1}

Perusahaan A adalah pengecer online yang sukses, yang menerima penghargaan untuk situs internet paling kewirausahaan, pada awalnya pemilik memimpikan gagasan untuk sebuah bisnis yang bisa menerima pesan hadiah untuk menerima Web dan memastikan pengiriman memenuhi target waktu. Perusahaan ini didirikan pada 1998, rencana bisnis dikembangkan pada awaltahun 1999, dan implementasinya dimulai pada pertengahan tahun 1999. Pemilik menginvestasikan 80.000 dolar, yang memprediksi bahwa profabilitas akan di capai dalam 4 tahun. Pada tahun 2093 situs ini diluncurkan pertama kali pada bulan juli, situs memiliki sekita 55.000 pemirsa pada setiap bulan, dalam 3 bulam pertama operasinya perusahaan tersebut memberikan hadiah sekitar 30.000 pelanggan.pada bulan april 2000 merekaberhasil mengumpulkan 15 juta dolarlebih. Untuk meningkatkan bisnis melakukan investasi dalam pemesanan online dan pemenuhan dalam hal penempatan staf dan infrastruktur. perusahaanA sekarang dapat memperkerjakan 60-70 karyawan dan secara konsisten masuk ke dalam 10 besar situs etiket Australia selama tahun 2001, perusahaan ini telah mengembangkan modal bisnisnya melalui berbagai aliansi dan akuisisi dan pengembangan dgn kisaran harga dan jenis kepribadian untuk membantu pelanggan, sehingga mereka tidak perlu daftar masuk lagi.

\section{Sudi kasus 2}

Perusahaan B adalah perusahaan pertama yang meindahkan ritel buku dan batu bata dan industri mortir secara one line, selain itu sejauh ini telah berbuat lebih banyak untuk menunjukkan bagaimana Web berasmsi konvensional tentang distribusi dari pada perusahaan B.

Hal ini telah menjadi identik dengan ecomeperesce dan ini adalah salah satu dari merek internet yang dikenal di seluruh dunia.

Ini adalah situs e-comerce yang paling banyak di kunjungi di Amerika sertkatdan dari satu dua atau tiga teratas di Inggris, Perancis, Jerman dan Jepang. Model Perusahaan B adalah perusahaan sederhana namun menarik. 
Perusahaan B mulai beroperasi mulai tahun 1995 oleh lulusan sains komputer inovasi yang menyadari potensi e- commerence di internet lebih awal sehingga dalam melakukan analisis terhadap 20 kelompok produk dan melakukan analisis nilai masing masing, hasil nilainya adalah buku karena kategori yang lebih besar, keragaman lebih besar dan resikonya yang lebih rendah. Perusahaan B biasanya merupakan barang terlaris dan pemesanan langsung dengan distributor yang dilakukan oleh pelanggan dengan menggunakan situs Webnya. Perusahaan B ini sangatmemungkinkan untuk mencapaipersediaan setara 70 pertahun hal ini berlawanan dengan rata-rata industri di antara penjual one line

\section{Mengindentifikasi peluang strategis Inovasi E-Bisnis}

Inovasi e-bisnis adalah transformasi digital dari proses bisnis yang memiliki efek mendalam pada praktek bisnis yang ada, selain itu menurut Shingh Inovasi bisnis adalah merangkulbadaya pada perusahaan, yang umumnya di gambarkan sebagai sistem makna bersama dalam sebuah organisasi terkait dengan internet dan pertumbuhan penggunaan dan penerapan komputer.

Indentifikasi dan penetapan strategis untuk perusahaan akanmenghasilkan pemahaman tentang inovasi dan justifikasi untuk meningkatkan bisnis. Daya saing dan layanan pelanggan.

\section{PENUTUP}

\section{A. Kesimpulan}

1. Untuk mengatasi situasi tersebut, pemerintah gencar menyusun strategi pemulihan bisnis UMKM di masa adaptasi kebiasaan baru. Salah satunya melalui program Pemulihan Ekonomi Nasional (PEN) dengan dikeluarkannya Bantuan Presiden Produktif untuk Usaha Mikro (BPUM).

2. Kepala Bidang Pemberdayaan Usaha Kecil, Dinas Koperasi dan UKM Kalbar, Anselmus mengatakan, selama masa pandemi COVD-19 terjadi peningkatan jumlah pelaku usaha mikro yakni sekitar 42.000 UMKM.

3. "Khusus untuk usaha mikro memang terjadi lonjakan yang luar biasa selama masa pandemi ini," kata Anselmus, saat mewakili Kepala Dinas Koperasi dan UKM Kalbar Ansfridus J Andjioe saat menjadi pemateri kegiatan webinar dengan tema 'Manfaat Program PEN bagi UMKM' di Pontianak, Kamis, 3 Desemer 2020. 
4. Anselmus menyatakan, program bantuan bagi UMKM yang digelontorkan pemerintah ini membuat jumlah pelaku usaha mikro bertambah. Berdasarkan tahun 2019 jumlah pelaku usaha mikro sebanyak 54 ribu. Namun, dengan bantuan dari pemerintah pusat, tercatat 96 ribu pelaku usaha mikro yang mengajukan bantuan dan akan terus bertambah.

5. "Melalui kebijakan ini juga diharapkan UMKM bisa berkontribusi meningkatkan perekonomian Indonesia yang semakin kokoh di tahuntahun mendatang. Terlebih, mempunyai komoditi atau produk unggulan yang bernilai ekspor dari tingkat desa, kecamatan, kabupaten atau kota hingga provinsi yang diyakini mampu bersaing di pasar global," jelasnya.

6. Anselmus mengatakan, agar UMKM bisa tumbuh di masa serba sulit seperti sekarang ini, pemerintah melalui Kementerian Koperasi dan UKM telah memberikan tiga stimulus. Bantuan stimulus tersebut terdiri dari kelonggaran pembayaran pinjaman, keringanan pajak UMKM selama 6 bulan serta transfer tunai untuk bisnis skala mikro.

\section{B. Saran}

1. Selama Pandemi berbagai inisiatif akan berhasil menarik peminat usaha, banyak UMKM untuk Go Digital menjadi kategori khusus melalui Galeri indonesia berdiri dan hingga akhir September tahun ini, sudah terdapat lebih dari 65 ribu seller UMKM yang bergabung dalam usaha melenial digital.

2. Untuk menguatkan dukungan terhadap UMKM, berkolaburasi dengan berbagai Stakeholder, khususnya bersamaPemerintah dengan mendukung program Bangsa Buatan Indonesia (BBI), yang dikolaborasikan dengan kampanye "Karena Lokal No.1 dan "Gerakan Pejuang Lokal" untuk menghadirkan deretan produk terbaik UMKM

3. Dalam Rangkaian kegiatan ini bertujuan mendorong para pelanggan untuk bangga membeli produk lokal, melalui usaha melenial UMKM yang sebagian besar dikelola oleh anak- anak muda di program Ideafest 2020 pada Nopember 2020, dengan kerjasama Pemerintah Daerah, termasuk mendukung pasar kreatif, juga meluncurkan Galeri mesin lokal bersama mentri Perindustrian untuk memudahkan UMKM dalam membeli alat produksi dengan mendaya gunakan UMKM kategori Kuliner, dengan mengadakan festifalOne line.

4. Flafon Festifal Kuliner Nasional Online, dalam menjalankan usaha dan mengadopsi teknologi Digital sebagai persiapan menghadapi industry go online diyakini akan dapat mengalami lonjakan peminat belanja One line ditengah pandemi Covid -19 seperti sekarang ini. 
5. Langkah lain yang bisa dilakukan adalah dengan melakukan kerjasama dengan kementrianLuar Negri, dan atase industri di luar negri, untuk melakukan proses negosiasi dalam hal perdagangan dengan GO National and International, secara digital melinial (digital One Line )

\section{DAFTAR PUSTAKA}

Kasmir, SE.,MM - Studi Kelayakan Bisnis.

Goegle Book, 1 April 2016 halaman 276

Mulyadi Nasution Bandung, - Manajemen Usaha Kecil

Sopee Indonesia, poltekkes - Kewirausahaan dan Manajemen Usaha Kecil

m. singh,. Waddell,E. Business Inovation and change Management, IRM Press London

A,Arora, A, Fosturi, A, Gambardella, Markets, for teknology, the Eonomies of Inovation, Mit Press, 2002.

Widyaiswara ahli Muda di PPSDM- migas. 